\title{
Comparison between Mineralogical Properties of Oak Forest and Un-Cultivated Soils in Iraqi Kurdistan Region
}

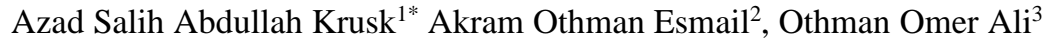 \\ ${ }^{I}$ Dept. of Chemistry, College of Science. University of Raparin, Kurdistan region-Iraq, azad.salih20@uor.edu.krd \\ ${ }^{2}$ Dept. of Soil and Water, College of Agricultural Engineering Sciences, Salahaddin University-Erbil, Kurdistan region-Iraq, \\ akram.esmail@su.edu.krd \\ ${ }^{3}$ Dept. of Forestry, College of Agricultural Engineering Sciences, Salahaddin Univ.-Erbil, Kurdistan region-Iraq, \\ othman.ali@su.edu.krd \\ *Correspondence: azad.salih20@uor.edu.krd
}

\begin{abstract}
This study was conducted to identify the mineralogical properties of oak forest and un-cultivated soils at 12 locations in the Iraqi Kurdistan region, which included (Brifca, Gara, and Matin) in Duhok governorate, (Awagrd, Bilah, and Malakan) in Erbil governorate, (Badawan, Bardanga, and Chwarta) in Sulaimani Governorate and (Bakhakon, Hawar, and Sartak) in Halabja governorate. Clay minerals were identified from X-ray diffraction data and peaks. Peak height is used as a rough indicator of the relative abundance of minerals. In general, the expansion of $14^{\circ} \mathrm{A}$ to $\cong 17^{\circ} \mathrm{A}$ in ethylene glycol treatment was not detected because measuring started from $5 \theta$ so that's why we cannot be differentiated between Chlorite and Smectite in that treatment. Swelling chlorite was the dominant mineral in these soils. While the miner clay mineral at that locations were Kaolinite. Mica was identified at all locations, while the dominant type of Mica at forest soils was Muscovite which was obtained from 6 sites, while Mica Biotite was obtained from 4 sites, but in un-cultivated sites, both types of mica recorded at 5 sites.
\end{abstract}

Keywords: Forest Soils, Un-cultivated soils, Clay minerals, Chlorite

Received: September 09 ${ }^{\text {th }}, 2020$ / Accepted: December 18 ${ }^{\text {th }}, 2020$ / Online: January $2^{\text {nd }}, 2021$

\section{Introduction:}

The climate of the Kurdistan Region is characterized by extraordinary conditions, with an expansive temperature distinction between day and night and between winter and summer. In summer, the temperature comes to exceed $45^{\circ} \mathrm{C}$ within the day at the southern boundaries of the three governorates, whereas within the northern edges it goes down well underneath $20^{\circ} \mathrm{C}$ to approximately $15^{\circ} \mathrm{C}$. Because of that, the climate of the Kurdistan region has been classified as semi-arid continental, which is to say hot and dry in summer and cold and rainy in winter. Spring and autumn are humid in comparison to summer and winter (FAO, 1999).

Forest soils in the north of Iraq are usually characterized by being shallow with some deep soils in the plains and valleys area. Forests are usually grown on non-covered rocks penetrated with some forest trees roots which lead to the weathering of parent materials. So, the characteristics of such soils are highly dependent on the nature of the parent material consistent directly (Yahya, 1982).

The plant cover, especially trees, has a great effect on soil chemical, mineralogical, physical, and biological properties of the soil. On the other hand types of forest trees had a significant effect on most of the soil characteristics. The properties of oak forest soils are differing from the soil properties of pine forest soils, and cypress forest soils as mentioned by Sheikh Abdullah (2012). 
Nutrients required for plant growth other than nitrogen and sometimes sulfur is initially supplied by chemical dissolution of primary minerals in the process known as weathering. vascular plants should accelerate weathering more than the activity of any likely pre-existing primitive terrestrial organisms such as algae and lichens, because of the much greater contact area between minerals and the huge mass of fine roots of the higher plants and because of plants much faster growth and internal storage of rock weathering derived cations (Berner, 1992 and 1995).

Al-Jaff and Essa (2020) mentioned that the transformation process of mica mineral to 2:1 expandable mineral in the rhizosphere was exceeded than in bulk soil. In general potassium release from mica, the structure was affected by $\mathrm{pH}$, Oxygen, and microorganisms' activity (Sheikh-Abdullah and Essa 2015).

There are numerous investigations about studying chemical and mineralogical properties of forest soils conducted by (Al-Jaff 2006, Muhammad, 2007, Sheilh-Abdullah 2012, Barwari 2013 and Ali 2015) but none of them included a special type of forest and they didn't cover different topographical locations for these reasons this investigation was selected to study the mineralogical properties of oak forest soils and comparing them to un-cultivated soils from Gara in Dohuk to Sartak in Halabja.

\section{Materials and methods}

This investigation was conducted from 1/7/2016 to 20/12/2018. Before soil sampling, several trips were made to identify the representative sites. The trips emphasis done to select the suitable and representative Oak forests and un-cultivated soils on one hand and to cover a wide spectrum of soil properties, on the other hand, For this purpose, 12 sites were selected in the Kurdistan region at each site two locations were selected, one of them was oak forest soil and the second one was un-cultivated soil, The total soil samples were 48 samples, collected according to field trips for laboratory analysis as shown from Table 1and Figure 1. Soil samples were air-dried and passed through a $2 \mathrm{~mm}$ sieve. Clay minerals were identified by X-Ray diffraction, the soil samples were prepared depending on the following steps:

1- Removal of soluble salts by distilled water according to Kunze and Dixon, (1986).

2- Carbonate minerals were removed by $(\mathrm{NaOAc}-$ at $\mathrm{pH}=5)$ as described by Kunze and Dixon, (1986).

3- Removal of organic matter by ( $\mathrm{NaOCl} 14 \%$ ), according to Anderson, (1963).

4- Free oxides were removed by (Sodium citrate Na3C6H5, Sodium bicarbonate NaHCO3, and Sodium dithionate Na2S2O4) using the method of (MEHRA and JACKSON, 1960).

After that the clay samples were divided to two parts, the first part was saturated with magnesium by $\mathrm{MgCl}_{2}$ $(0.01 \mathrm{~N})$ and the second part was saturated with potassium by $(\mathrm{KCl})(0.01 \mathrm{~N})$, and five slides were prepared for each sample two of them from magnesium saturated part which was ( $\mathrm{Mg}$ saturated air dry and magnesium saturated treated with ethylene glycol, and three slides from Potassium saturated part which was (potassium air dry, potassium heated upon $350^{\circ} \mathrm{C}$, and potassium heated upon $550^{\circ} \mathrm{C}$.

Table 1. Shows geographical coordinates of the sites from which the soil samples were taken

\begin{tabular}{|c|c|c|c|c|}
\hline Governorate & Location & Latitude & Longitude & Altitude (m) \\
\hline \multirow{3}{*}{$\frac{\vec{a}}{\stackrel{\Xi}{0}}$} & Gara & $37^{\circ} 01^{\prime} 40.24^{\prime \prime}$ & $43^{\circ} 20^{\prime} 04.91^{\prime \prime}$ & 1193 \\
\hline & Matin & $37^{\circ} 04^{\prime} 51.73^{\prime \prime}$ & $43^{\circ} 15^{\prime} 58.30^{\prime \prime}$ & 955 \\
\hline & Brifca & $36^{\circ} 48^{\prime} 32.89^{\prime \prime}$ & $43^{\circ} 10^{\prime} 42.19^{\prime \prime}$ & 778 \\
\hline \multirow{3}{*}{ 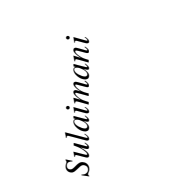 } & Bardanga & $36^{\circ} 22^{\prime} 14.45^{\prime \prime}$ & $44^{\circ} 44^{\prime} 56.71^{\prime \prime}$ & 927 \\
\hline & Badawan & $36^{\circ} 06^{\prime} 18.99^{\prime \prime}$ & $44^{\circ} 44^{\prime} 16.64^{\prime \prime}$ & 676 \\
\hline & Chwarta & $35^{\circ} 42^{\prime} 42.40^{\prime \prime}$ & $45^{\circ} 35^{\prime} 33.03^{\prime \prime}$ & 1204 \\
\hline \multirow{3}{*}{$\frac{\bar{\Xi}}{\frac{\vec{J}}{ \pm}}$} & Awagrd & $36^{\circ} 13^{\prime} 34.36^{\prime \prime}$ & $44^{\circ} 28^{\prime} 15.17^{\prime \prime}$ & 903 \\
\hline & Bilah & $36^{\circ} 50^{\prime} 55.76^{\prime \prime}$ & $44^{\circ} 04^{\prime} 35.76^{\prime \prime}$ & 511 \\
\hline & Malakan & $36^{\circ} 28^{\prime} 24.60^{\prime \prime}$ & $44^{\circ} 33^{\prime} 44.40^{\prime \prime}$ & 1202 \\
\hline
\end{tabular}




\begin{tabular}{lllll}
\hline.$\frac{0}{3}$ & Bakhakon & $35^{\circ} 15^{\prime} 43.05^{\prime \prime}$ & $46^{\circ} 06^{\prime} 34.75^{\prime \prime}$ & 1143 \\
$\frac{\mathbb{3}}{\mathbb{2}}$ & Hawar & $35^{\circ} 09^{\prime} 51.03^{\prime \prime}$ & $46^{\circ} 06^{\prime} 27.42^{\prime \prime}$ & 1134 \\
\hline
\end{tabular}

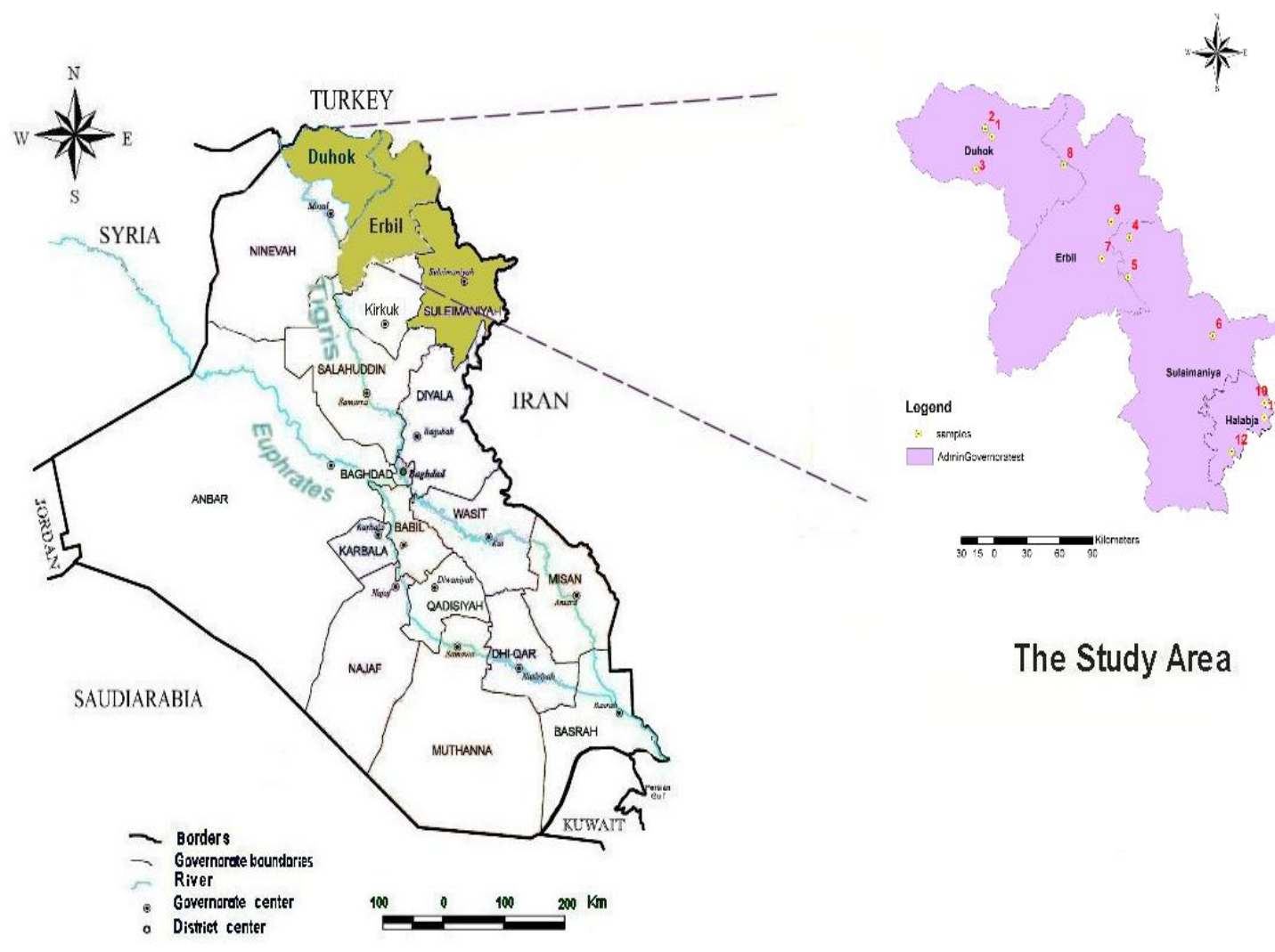

Figure 1. Location map showing the investigated positions

\section{Results and discussion}

The common unit for the measurement of the distance between planes, known as lattice spacing or inter micellar spacing, is the angstrom $(1 \AA=0.1 \mathrm{~nm})$, which corresponds to the unit of X-ray wavelength.

Pre-treatment of the clay sample, like the saturation of the mineral with $\mathrm{K}, \mathrm{Mg}$, or $\mathrm{Mg}$ plus glycolation, and heating at $550{ }^{\circ} \mathrm{C}$, effects certain shifts in spacing that are characteristic of the type of mineral.

Peak height was used as a rough indicator of relative abundance of minerals (April, et.al, 2004). In general, the expansion of $14 \AA$ to $17 \AA$ in ethylene glycol treatment was not detected because measuring started from $5 \theta$ (degree 5 theta), so chlorite cannot be differentiated from smectite under this treatment.

Real chlorite was characterized by $14 \AA$ reflection, which remains the same under all treatments, while swelling chlorite was characterized by $14 \AA$ reflection, and remains the same in $\mathrm{Mg}$-saturation air dry, ethylene glycol saturation, $\mathrm{K}$-saturation air dry, $\mathrm{K}$-saturation upon heating to $350^{\circ} \mathrm{C}$, while it disappears in $\mathrm{K}$-saturation upon heating to $550^{\circ} \mathrm{C}$. The difference between the two types of chlorite (Real and Swelling) is depending on the resistance of a mineral to the destroy in heating treatment, i.e. the real chlorite is high resistance for the temperature and this depending on well crystalline structure, for distinguishing between real chlorite and swelling chlorite at $550^{\circ} \mathrm{C}$ third-order of chloride d-spacing was used which was equal to $(4.2-4.7)$.

The identification of dominant clay minerals depended on the peak height as shown from figures (2 to 5). In general, the swelling chlorite being the dominant mineral in the forest soils. 
The occurring of swelling chlorite in investigated soils is due to the deposition of hydroxyl materials (FeHydroxides or Mg-hydroxides) within the interlayer spaces of expansible layer silicate such as smectite because an increase of such elements in the surface horizon of soils could be due to positive differences between element input fluxes, principally by mass flow, minerals weathering, and organic matter mineralization and element output fluxes (Seguin et al., 2005).

Dixon and Weed, (1989) were observed that more frequently hydroxyl inter layering is greatest in the surface horizon and decrease with depth, this depends on the amount and types of complexes between organic acids such as fulvic and humic with cations in soil solution as we know that the studied soils were calcareous and the $\mathrm{Ca}^{+2}$ and $\mathrm{Mg}^{+2}$ are dominant in soil solution and these cations are ready to make a complexes with these organic acids, and all divalent cations complexes with humic acids are non-soluble, this is the first stage of hydroxyl interlayer formation inside the interlayers of 2:1 expandable minerals.

Numerous studies have been done on these complexes in the Kurdistan region well support this hypothesis, such as (Muhammad, 2007 and Sheikh Abdullah, 2012). These complexes are non-soluble and nonleachable, so they were dominant in the surface horizon and decreased with depth these findings are in agreement with Dixon and Weed, (1989).

In general, both types of mica (biotite and muscovite) and even illite minerals are identified from the first order at two groups of d-spacing, the first one started from $9.9 \AA$ till $10.5 \AA$ which represents the low weathered mica, the $10.5 \AA$ exactly d-spacing represent palygorskite mineral. The second group of identify mica groups start from $10.5 \AA-11 \AA$ which represents the high weathered mica while the $11 \AA$ is the point of starting interstratified mineral identification.

The distinguish between two types of mica which were muscovite and biotite depending on the secondorder of mica $(5 \AA)$, in muscovite the peak of the second-order is always strong and high while it's disappeared or very weak in biotite. Also, the six orders of mica were used for distinguishing between mica biotite and muscovite, if the six order of mica was equal to $10.5 \AA$, it means that the present mica was muscovite, but if the six order was equal to 10.54 it means that the present mica was biotite The disappearing of $10 \AA$ in the first three treatments ( $\mathrm{Mg}$ air dry, $\mathrm{Mg}$ plus ethylene glycol, and $\mathrm{K}$ air dry) at Bilah and Badawan sites, with appearing of $14 \AA$ in these above treatments and then follow by appearing of $10 \AA$ in $550{ }^{\circ} \mathrm{C}$ treatment leads to thinking about high weathering in these location, i.e. the high weathering of mica mineral which caused by high precipitation $(1256 \mathrm{~mm} /$ year $)$ in these locations lead mica weathering toward $14 \AA$ intensively so that's why we didn't find $10 \AA$ in first three treatments at the same time the $10 \AA$ peak founded in $550^{\circ} \mathrm{C}$ treatment, which explain that the source of $14 \AA$ in these soils is mica and the heating treatment $550{ }^{\circ} \mathrm{C}$ caused to collapsing the lattices and shift toward $10 \AA$. The appearance of $12 \AA$ at potassium air dried treatment which belongs to interstratified minerals was supports this explanation. Kaolinite is characterized by $7 \AA$ reflection and remains the same in $\mathrm{Mg}$-saturation air dry, ethylene glycol-saturation, $\mathrm{K}$-saturation air dry, and $\mathrm{K}$-saturation $350^{\circ} \mathrm{C}$, while it disappears in $\mathrm{K}$-saturation $550^{\circ} \mathrm{C}$.

Swelling chlorite was appeared in all studied soils (forest and non-cultivated), while real chlorite disappeared in all locations, since $14 \AA \mathrm{d}$-spacing disappeared in treatment of $550^{\circ} \mathrm{C}$, while to make us sure that swelling chlorite was rather than vermiculite in studied soils depending on the third order of chloride which was $(4.2-4.7) \AA$ which appear in the $550^{\circ} \mathrm{C}$, which indicated that swelling chlorite represents in all studied soil samples. Swelling chlorite was recorded at 11 locations of forest and uncultivated soils as shown in tables ( 2 and 3 ) it means that $92 \%$ of the forest and un-cultivated soil samples recorded the highest swelling chlorite content except for Brifca forest site and Malakan un-cultivated site the dominant clay mineral at these sites was muscovite which represent $8 \%$ of the studied soil samples. 

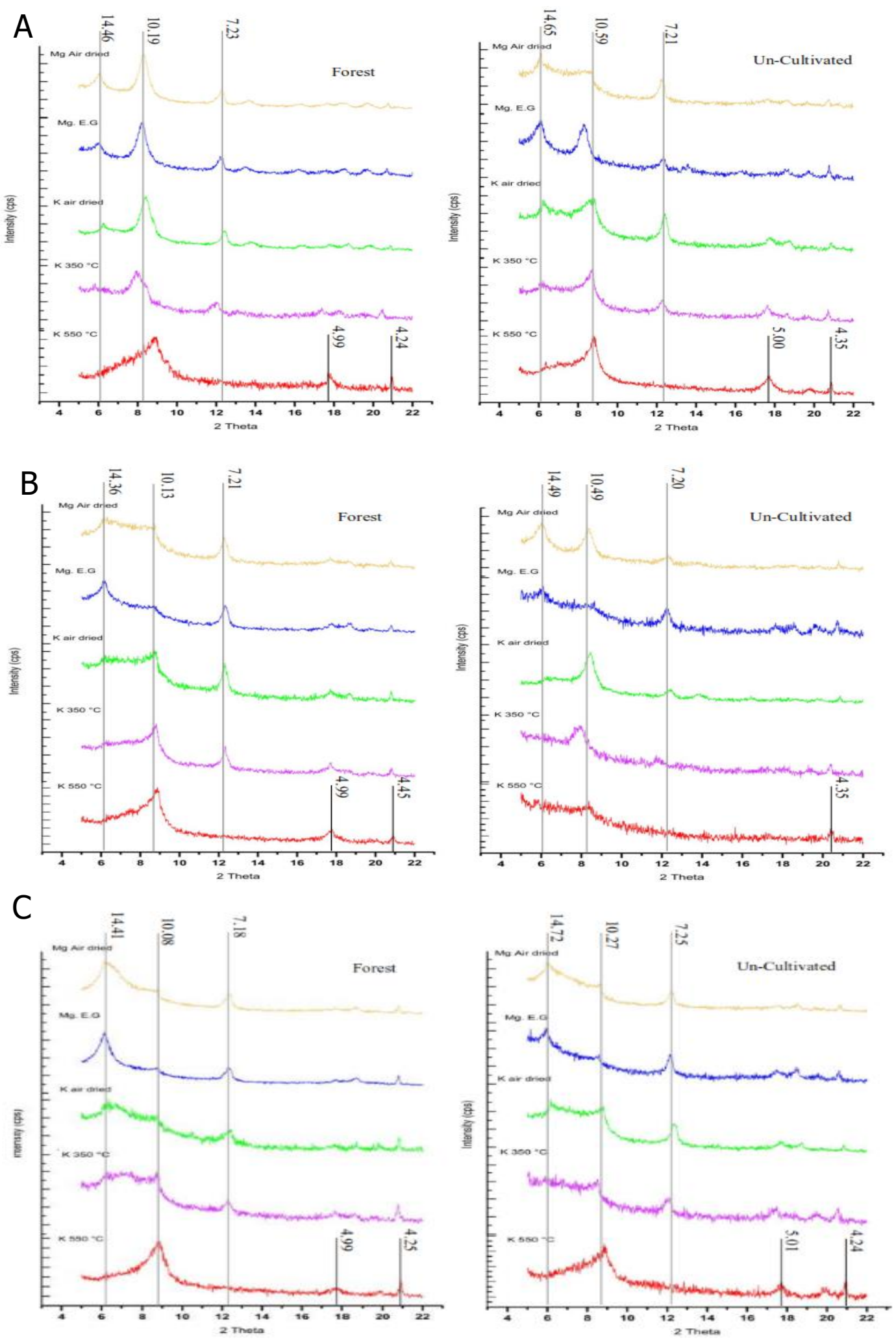

Figure 2. X-ray diffraction pattern for clay fraction in (A: Brifca, B: Gara, C: Matin) sites at Duhok Province 

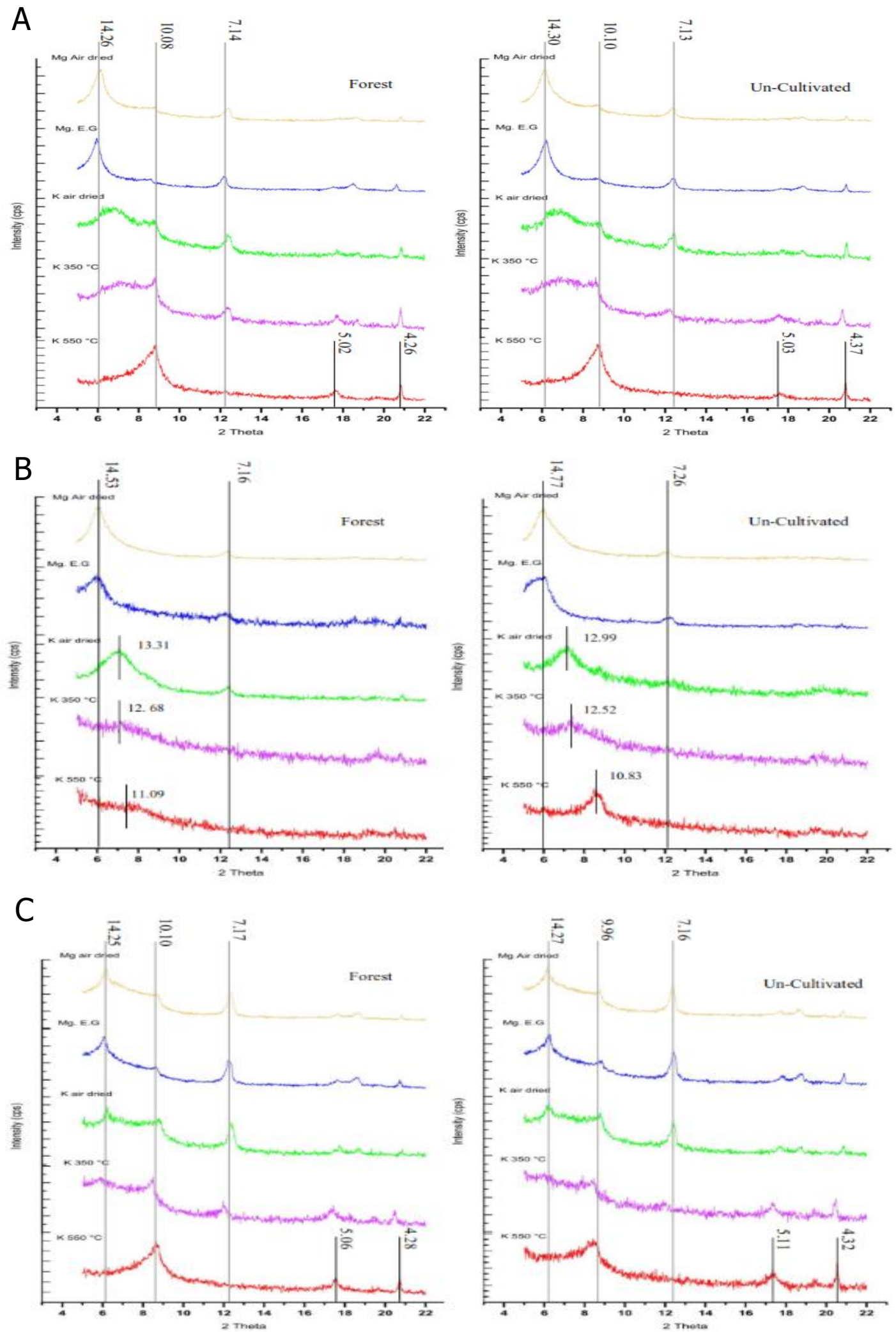

Figure 3. X-ray diffraction pattern for clay fraction in (A: Awagrd, B: Bilah, C: Malakan) sites in Erbil Province 

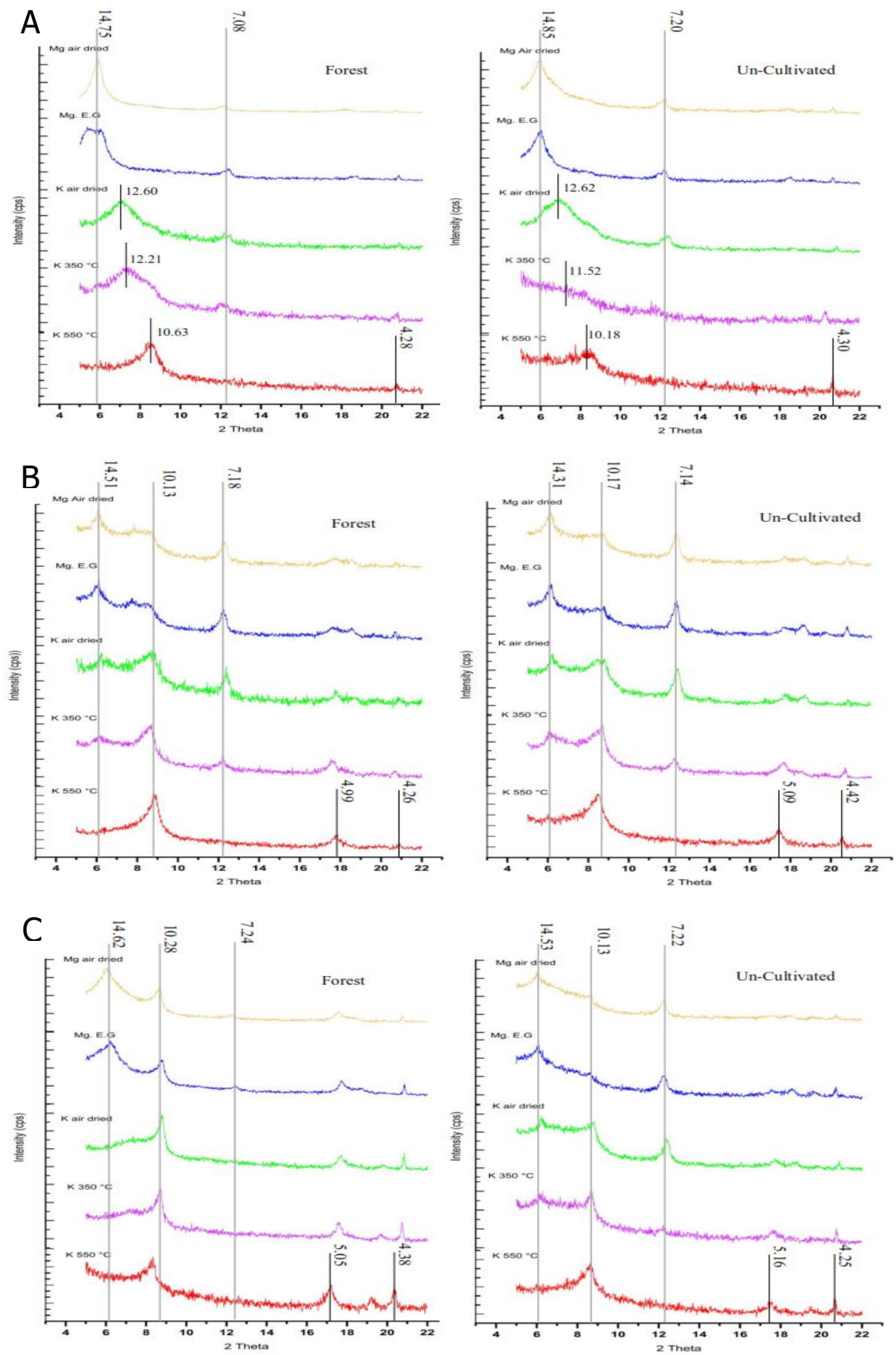

Figure 4. X-ray diffraction pattern for clay fraction in (A: Badawan, B: Bardanga, C: Chwarta) sites in Sulaimani Province 

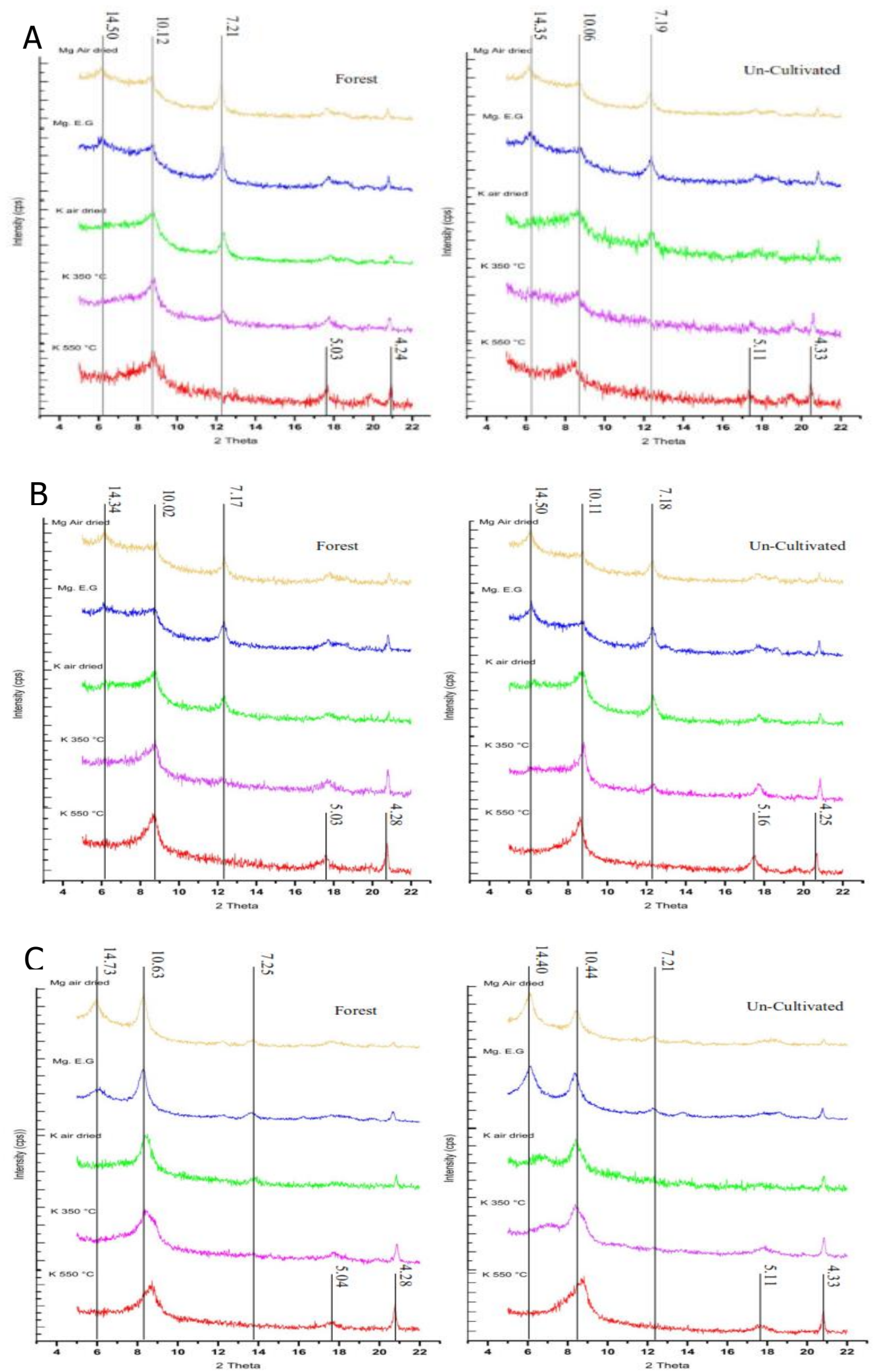

Figure 5. X-ray diffraction pattern for clay fraction in (A: Bakhakon, B: Hawar, C: Sartak) sites in Halabja Province 
Table 2. The abundance of clay minerals in forest soil samples

\begin{tabular}{|c|c|c|c|c|c|}
\hline Site & S. Chlorite & R. Chlorite & Mica & Kaolinite & Non-clay minerals \\
\hline Brifca & +++ & & $\begin{array}{c}\text { ++++ } \\
\text { Muscovite }\end{array}$ & ++ & $\begin{array}{c}\text { Quartz } \\
\text { K-Feldspar }\end{array}$ \\
\hline Gara & ++++ & & $\begin{array}{c}+++ \\
\text { Muscovite }\end{array}$ & ++ & $\begin{array}{c}\text { Quartz } \\
\text { K-Feldspar }\end{array}$ \\
\hline Matin & ++++ & & $\begin{array}{c}+++ \\
\text { Biotite }\end{array}$ & ++ & $\begin{array}{c}\text { Quartz } \\
\text { K-Feldspar }\end{array}$ \\
\hline Awagrd & ++++ & & $\begin{array}{c}+++ \\
\text { Biotite }\end{array}$ & ++ & $\begin{array}{l}\text { Quartz, Dolomite } \\
\text { K-Feldspar }\end{array}$ \\
\hline Bilah & ++++ & & - & ++ & Quartz \\
\hline Malakan & ++++ & & $\begin{array}{c}+++ \\
\text { Muscovite }\end{array}$ & ++ & $\begin{array}{c}\text { Quartz } \\
\text { K-Feldspar }\end{array}$ \\
\hline Badawan & ++++ & & & ++ & $\begin{array}{c}\text { Quartz, Dolomite } \\
\text { K-Feldspar }\end{array}$ \\
\hline Bardanga & ++++ & & $\begin{array}{c}+++ \\
\text { Muscovite }\end{array}$ & ++ & $\begin{array}{c}\text { Quartz, Dolomite } \\
\text { K-Feldspar }\end{array}$ \\
\hline Chwarta & ++++ & & $\begin{array}{c}+++ \\
\text { Muscovite }\end{array}$ & ++ & Quartz, K-Feldspar \\
\hline Bakhakon & ++++ & & $\begin{array}{c}+++ \\
\text { Muscovite }\end{array}$ & ++ & $\begin{array}{c}\text { Quartz, Dolomite } \\
\text { K-Feldspar }\end{array}$ \\
\hline Hawar & ++++ & & $\begin{array}{c}+++ \\
\text { Biotite }\end{array}$ & ++ & $\begin{array}{c}\text { Quartz } \\
\text { K-Feldspar }\end{array}$ \\
\hline Sartak & ++++ & & $\begin{array}{c}+++ \\
\text { Biotite }\end{array}$ & ++ & $\begin{array}{c}\text { Quartz, Dolomite } \\
\text { K-Feldspar }\end{array}$ \\
\hline
\end{tabular}

Table 3. The abundance of clay minerals in un-cultivated soil samples

\begin{tabular}{|c|c|c|c|c|c|}
\hline Site & S. Chlorite & R. Chlorite & Mica & Kaolinite & Non-clay minerals \\
\hline Brifca & ++++ & & +++ & ++ & Quartz \\
\hline Brilca & ++++ & & Muscovite & & K-Feldspar \\
\hline Gara & ++++ & & $\begin{array}{c}+++ \\
\text { Pigtito }\end{array}$ & ++ & Quartz \\
\hline & & & $\begin{array}{c}\text { B1otite } \\
+++\end{array}$ & ++ & $\begin{array}{l}\text { K-Feldspar } \\
\text { Quartz }\end{array}$ \\
\hline Matin & ++++ & & Muscovite & & K-Feldspar \\
\hline Awagrd & ++++ & & $\begin{array}{c}+++ \\
\text { Biotite }\end{array}$ & ++ & $\begin{array}{c}\text { Quartz, Dolomite } \\
\text { K-Feldsnar }\end{array}$ \\
\hline & & & & & Quartz, Dolomite \\
\hline Bilah & ++++ & & - & ++ & K-Feldspar \\
\hline Malakan & +++ & & ++++ & ++ & Quartz \\
\hline & & & Muscovite & & $\begin{array}{c}\text { K-Feldspar } \\
\text { Quartz, Dolomite }\end{array}$ \\
\hline Badawan & ++++ & & - & TT & K-Feldspar \\
\hline Bardanga & ++++ & & +++ & ++ & Quartz \\
\hline & & & $\begin{array}{c}\text { Muscovite } \\
+++\end{array}$ & ++ & $\begin{array}{l}\text { K-Feldspar } \\
\text { Quartz }\end{array}$ \\
\hline Chwarta & ++++ & & Biotite & TT & K-Feldspar \\
\hline Bakhakon & ++++ & & $\begin{array}{c}+++ \\
\text { Riotite }\end{array}$ & ++ & Quartz, Dolomite \\
\hline & & & $\begin{array}{c}\text { B1otite } \\
+++\end{array}$ & ++ & $\begin{array}{c}\text { K-Feldspar } \\
\text { Quartz }\end{array}$ \\
\hline Hawar & ++++ & & Muscovite & TT & K-Feldspar \\
\hline Sartak & ++++ & & $\begin{array}{c}+++ \\
\text { Biotite }\end{array}$ & ++ & $\begin{array}{c}\text { Quartz } \\
\text { K-Feldspar }\end{array}$ \\
\hline
\end{tabular}

$\begin{array}{llc}++++ & \text { Dominant } & 50-90 \% \\ +++ & \text { Major } & 20-50 \% \\ ++ & \text { Minor } & 5-20 \% \\ + & \text { Trace } & <5 \% \\ \text { Non-clay minerals } & & \text { detected }\end{array}$


The dominant type of mica at forest sites was muscovite which was obtained from 6 sites, while biotite obtained from 4 sites. But in un-cultivated sites both types of mica (biotite and muscovite) recorded at 5 sites as shown in table (2 and 3 ).

It appears that muscovite was recorded from $50 \%$ of forest sites and $41.67 \%$ of un-cultivated soils, while biotite recorded at $33.3 \%$ of forest sites and $41.67 \%$ of un-cultivated soils; both mica mineral types were not recorded from $16.67 \%$ of studied soils or not recorded at Bilah and Badawan sites. The kaolinite clay mineral has existed in miner amount $(5-20) \%$ of all forest and un-cultivated soils. Table (2 and 3$)$ also shown that non-clay minerals such as (Quartz and K-Feldspar) were recorded from all studied forest and uncultivated soils, except Bilah forest site, the only non-clay minerals which observed at this site was quartz, while the Dolomite was recorded from five forest soils and four un-cultivated soils which were equal to $41.67 \%$ and $33.33 \%$ of the studied forest and un-cultivated soils respectively.

\section{Conclusion}

Based on the obtained results from the current study, the order for dominant clay minerals of studied soils was as follows: (Swelling chlorite > mica muscovite) which were recorded at (92\% and 8\%) of the studied soils respectively. The dominant mica mineral in forest soils was mica muscovite which was more weatherable.

\section{References}

Ali, N. S. (2015). Temporal Variation of the Nutrients Content of the Forest Trees and Soils at Hijran and Zawita Sites. College of Agriculture, Salahaddin University- Erbil, Kurdistan Region-Iraq.

Al-Jaff, B. O. A. (2006). Natural Occurrence and Formation of Interstratified Minerals with Influence Factors in Some Iraqi Soils. PhD Dissertation submitted to College of Agriculture University of Baghdad.

Al-Jaff, B. O. and Essa, S. Kh. (2020). Effect of Plant Coverage on Mineralogical Changes of Mica in Rhizosphere. Iraqi journal of Agricultural Science, 51 (1). Pp: $493-499$.

Anderson, J. U. (1963). An improved pretreatment for mineralogical analysis of samples containing organic matter. Clays and Clay Minerals. 10 (1), pp. 380-388.

April, R. H., Keller, D. and Driscoll, C. T. (2004). Smectite in spodosols from the Adirondack Mountains of New York. Clay Minerals. 39 (1), pp. 99-113.

Barwari, V. I. H. (2013). Soil Physic-Chemical Properties as Influenced by Slope Position Under Different Vegetation Covers In Duhok Governorate. M.Sc. Thesis Submitted to the Council of the Faculty of Agriculture and Forestry, University of Duhok. Pp 137.

Berner R. A. (1992). Weathering, Plants, and the Long-Term Carbon Cycle. Geochimica et Cosmochimica Acta 56: 3225 - 3231.

Berner, R. A. (1995). Chemical Weathering and its Effect on Atmospheric $\mathrm{CO}_{2}$ and Climate. Chemical Weathering Rates of Silicate Minerals (White, A.F. and Brantly, S,L., Eds.) Reviews in Mineralogy 31, 565 - 583.

Dixon, J. B. and Weed, S. B. (1989). Minerals in Soil Environments. In: Methods of Soil Analysis, Part 3. Chemical Methods. Madison: Soil Science Society of America. pp. 357-404.

FAO. Food and Agricultural Organization of the United Nations. (1999). State of the World's Forests. Rome. pp. 168.

Kunze, G. W. and Dixon, J. B. (1986). Pretreatment for Mineralogical Analysis. In: A. KLUTE, ed. Methods of Soil Analysis: Part 1 Physical and Mineralogical Methods. Madison,USA: American Society of Agronomy. pp. 1188.

Mehra, O. P. and Jackson, M. L. (1960). Iron Oxide Removal From Soils and Clays By a Dithionite-Citrate System Buffered With Sodium Bicarbonate. Clays and Clay Minerals. pp. 317-327.

Muhammad, D. A. (2007). The Interaction between Organic Matter and Semectite in Some Iraqi Soils of Different agricultural Land Use. PhD Dissertation submitted to College of Agriculture University of Sulaimani - Iraq.

Seguin, V., Courchesne, F., Gagnon, C., Martin, R. P., Naftel, S. J. and W. Skinner. (2005). Mineral Weathering in the Rhizosphere of Forested Soil. In P. M. Huang and G. R. Gobran (Ed) Biogeochemistry of Trace Elements in the Rhizosphere. Elsevier. Amsterdam, Netherlands. P. 29 - 55.

Sheikh Abdullah Sh. M. (2012). Effect of Plant on Transformation of Mica to Expandable Minerals in Some Forest Soils of Iraqi Kurdistan Region. Ph.D Dissertation, Submitted to the Council of Faculty of Agriculture Sciences, University of Sulaimani Iraq. Pp: 161

Sheikh Abdullah, S. M and Essa, S. Kh. (2015). The Morphological Features of Mica and Chlorite Minerals in Fine Sand Fraction in Some Forest Soils in Sulaymaniyah Governorate, Kurdistan. International journal of plant, Animal and Environmental Science. 5 (2). Pp: 97 - 104.

Yahya, A. M. (1982). Genesis and Classification of Zawita Forest in Duhok Province. Msc Thesis Submitted to College of Agriculture and Forestry, Mosul University, Iraq. 